\title{
Effects of ionizing radiation on bone neoformation. Histometric study in Wistar rats tibiae ${ }^{1}$
}

\author{
Efeitos da radiação ionizante na neoformação óssea. \\ Estudo histométrico em tíbias de ratos
}

\begin{abstract}
Susette Cavicchioli Lucatto ${ }^{\text {I }}$, Arnaldo Guilherme ${ }^{\text {II }}$, Luciano Lauria Dib ${ }^{\text {III }}$, Helena Regina Comodo Segreto ${ }^{\text {IV }}$, Maria Tereza de Seixas Alvesv, Emne Hammoud Gumieiro ${ }^{\text {VI }}$, Ricardo Schmitutz Jahn ${ }^{\text {VI }}$, Ronaldo Antonio Leite ${ }^{\text {VI }}$
\end{abstract}

IMaster, Department of Otorhinolaringology and Head and Neck Surgery, UNIFESP, Sao Paulo, Brazil. Responsible for technical procedures, acquisition and interpretation of data and manuscript preparation.

IIPhD, Associate Professor, Department of Otorhinolaringology and Head and Neck Surgery, UNIFESP, Sao Paulo, Brazil. Tutor, responsible for intellectual and scientific content of the study, and manuscript critical revision.

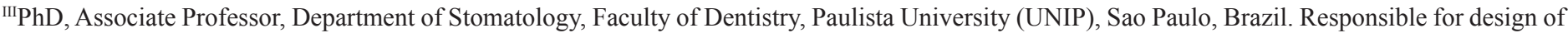
animal experimental model and manuscript critical revision.

${ }^{\text {IV }} \mathrm{PhD}$, Associate Professor, Department of Oncology, UNIFESP, Sao Paulo, Brazil. Responsible for the radiotherapy in the animals and manuscript critical revision.

${ }^{\mathrm{v}} \mathrm{PhD}$, Associate Professor, Department of Pathology, UNIFESP, Sao Paulo, Brazil. Responsible for the histological examination and manuscript critical revision.

${ }^{\mathrm{VI} F e l l o w} \mathrm{PhD}$ degree, Department of Otorhinolaringology and Head and Neck Surgery, UNIFESP, Sao Paulo, Brazil. Involved with technical procedures, acquisition and interpretation of data.

\begin{abstract}
PURPOSE: Comparing the ionizing radiation effects on bone neoformation of rats tibiae previously submitted to radiotherapy with a single dosage of $30 \mathrm{~Gy}$ with the contralateral tibiae that have received secondary radiation.

METHODS: In thirty male Wistar rats, 30 days before surgical procedure when round defects would be created on the bone, the right tibia was irradiated with $30 \mathrm{~Gy}$ and the left tibia received a calculated secondary radiation dose of 7 Gy. Sacrifices were performed after 4, 7, 14, 21, 56 and 84 postoperative days and both tibiae were removed for histological processing.

RESULTS: The left tibiae that received the dose of $7 \mathrm{~Gy}$ has shown more bone neoformation from $14^{\text {th }}$ postoperative days, giving evidences of less damage to cellular population responsible by bone neoformation. On the other hand, the dose of $30 \mathrm{Gyon}$ right tibiae did not exhibit significant differences among the periods, suggesting damage of long-lasting or even permanent duration.

CONCLUSION: Tibiae submitted to radiation dose of 30Gy have shown more damage to bone cells than tibiae that received secondary radiation dose of $7 \mathrm{~Gy}$, especially observed on $14^{\text {th }}, 56^{\text {th }}$ and $84^{\text {th }}$ postoperative days.
\end{abstract}

Keywords: Radiation Injuries, Experimental. Bone Regeneration. Tibia. Rats.

\section{RESUMO}

OBJETIVO: Comparar os efeitos da radiação ionizante na reparação óssea em tíbias de ratos, submetidas à radioterapia prévia com doses 30Gy, com as tíbias contralaterais que receberam radiação secundária.

MÉTODOS: No total, 30 ratos Wistar machos foram submetidos à cirurgia para realização de defeitos circulares em ambas as tíbias de cada rato, com radioterapia prévia de 30 dias, sendo que a tíbia direita recebeu a dose de 30 Gy e tíbia esquerda a dose de radiação secundária calculada em 7Gy. Os sacrifícios ocorreram em 4, 7, 14, 21, 56 e 84 dias da realização do defeito ósseo e as tíbias foram removidas para processamento histológico.

RESULTADOS: O grupo de 7Gy apresentou maior neoformação a partir do período de 14 dias, indicando pouco dano aos elementos celulares responsáveis pela reparação óssea, enquanto que o grupo de 30Gy não apresentou diferenças significantes entre os períodos, sugerindo um dano de efeito prolongado ou até mesmo permanente.

CONCLUSÃO: As tíbias irradiadas com 30Gy apresentaram maior dano às células ósseas do que as tíbias que receberam radiação secundária de 7Gy, principalmente observadas nos períodos de 14, 56 e 84 dias.

Descritores: Lesões Experimentais por Radiação. Regeneração Óssea. Tíbia. Ratos. 


\section{Introduction}

The treatment of cancer on head and neck region results in great bone loss that leads patients to need bone graft and/or osseointegrated implants. In most cases the combined radiotherapy with high doses damages the remaining bone and tissues, which impair the bone neoformation in quantity and quality.

Mandibular osteoradionecrosisis is the main complication that becomes difficult the treatment of such patients. The incidence can vary from $2 \%$ to $25 \%{ }^{1}$, and depends on total dose and dose per fraction. Frequently it is associated with injuries to buccal tissues and other factors like tumor location, type of surgery and elapsed time after radiotherapy, whose risk can exist for undefined time ${ }^{2}$.

However, evaluation studies on possibility of manipulating bone distant from the primary site of radiation target still not were done. Despite the strict delimitation of the irradiation field size, tissues far from the primary site also received ionizing radiation, but with less energy. Doses lower than 65Gy might not cause osteoradionecrosis on the primay site $^{1}$, but JereczekFossa et $a l .{ }^{3}$ found that retromolar region and ascendant ramus have more effects of radiation than mandibular condyles and mental symphysis and Parliament et al. ${ }^{4}$ verified that cases of buccal cancer usually received higher doses of irradiation than in nasopharynx region.

According to some authors, low doses from 2.5 to $5 \mathrm{~Gy}$, similar to the doses found on distant tissues have contradictory effects: they can stimulate or impair the bone neoformation ${ }^{5,6}$. Only Bures and Wuehrmann ${ }^{7}$ evaluated the radiation effects on irradiated and non-irradiated tibiae of rats, and they found reduction on bone apposition with high doses.

For a safe manipulation of bone tissues for rehabilitation of patients submitted to radiotherapy, it becomes important to analyze the structure of remaining bone as support to implants and or graft.

The aim of this experimental investigation was to perform a histometric evaluation of bone neoformation in defects created on tibiae of rats previously submitted to radiotherapy with doses of $30 \mathrm{~Gy}$ and on the contralateral tibiae that received secondary radiation dose calculated in $7 \mathrm{~Gy}$, in order to compare the effects of different irradiation doses on bone tissue.

\section{Methods}

This experiment was approved by the ethics committee of Federal University of Sao Paulo (UNIFESP) and followed the ethical code for animal experimentation of the Council for International Organization of Medical Sciences.

To carry out the study, it was used 30 male Wistar rats (Rattus norvegicus albinus), between 90 and 120 days of age and average weight of $400 \mathrm{~g}$.In polycarbonate cages, 5 animals were hosted with ad libitum access to rodent chow pellet (20g/day) and acidified drinking water $(\mathrm{pH}=2.8-3.1)$.

\section{Anesthesia}

Animals were anesthetized before irradiation and surgical procedure to create the defects. The anesthesia was induced with ketamine $0.1 \mathrm{mg} / 100 \mathrm{mg}$ body weight and xylazine $0.08 \mathrm{mg} / 100 \mathrm{mg}$ by intraperitoneal route.

\section{Radiation procedure}

The radiation of the animals followed the protocol of Ohrnell et al. ${ }^{8}$. In rat, the application of $30 \mathrm{~Gy}$ caused a significant reduction of the bone regeneration capacity but acute effects that were well supported by the animal. When a single dose of30Gy was compared to clinical practice it would correspond to approximately 50-70Gy applied in fractioned radiotherapy ${ }^{8}$.

Before radiation, the animals were subjected to a digital simulator of radiation, to guarantee a homogeneous dose of radiation. The radiation procedure was carried out in a Cobalt 60 equipment 30 days before the surgery. After anesthesia, 10 to 14 animals were simultaneously immobilized in a transparent acrylic plate. The right tibiae were put in a field of $20 \times 20 \mathrm{~cm}$ size and $80 \mathrm{~cm}$ source-skin distance and immobilized with a plastic fastener. The left paws and tails were fixed and put out of the field of radiation, but receiving about $7 \mathrm{~Gy}$ as it was calculated.

\section{Surgical procedure}

The animals were separated in six groups of 5 animals for each period: 4, 7, 14, 21, 56 e 84 postoperative days. The surgical procedures were performed 30 days after the radiation, given that the acute local side effects (epithelial desquamation, erythema and loss of hair) and systemic symptoms (illness and fatigue) after a dose of $30 \mathrm{~Gy}$ were reverted in the first three weeks ${ }^{8}$ and the interval of time between the radiation and the surgery does not influence the bone regeneration ${ }^{9}$.

The animals were anaesthetized, and both legs were shaved and washed with iodine-povidine. The operation was effectuated in sterile environment and with a gentle surgical technique. A longitudinal linear incision of approximately $2 \mathrm{~cm}$ in the medial region of the tibiae was made to expose the subcutaneous tissue and the musculature. The periosteum was 
exposed and incised, exposing the bone tissue of the medial portion of the tibiae metaphysis.

The circular monocortical defects of $3 \mathrm{~mm}$ of diameter were created with trephine burs under profuse and constant irrigation with saline sterile solution to avoid thermal damage to the tissues. The depth of bone defect was about 4 to $5 \mathrm{~mm}$.

The wound was closed in layers; the periosteum and muscular tissue were sutured with resorbablesuture4-0 and the skin was sutured with nylon 4-0 suture. A dose of 16.000UI of antibiotic benzatil-penicillin was given by intramuscular injection after surgery; paracetamol in the dose of $500 \mathrm{mg} / 500 \mathrm{ml}$ of water to drink was administered to the animals in the first two postoperative days.

\section{Histological analysis}

In the periods previously established at $4,7,14,21$, 56 and 84 days after surgery, subgroups of five animals each were sacrificed by an overdose of anesthetic. Skin around bone was carefully removed and the tibiae were cut off with a bone saw. The pieces obtained were conditioned in labeled containers with $10 \%$ formaldehyde solution for at least 72 hours. After fixation the muscular tissues were removed and the circular defects with a $3 \mathrm{~mm}$ margin of surrounding bone were sawn transversely. The specimens were decalcified in a 10\% EDTA solution during 24 to 36 hours, and then washed in running water for 24 hours. Dehydration was prosecuted in successive passages in alcoholic and xylol solutions in automatic equipment. Specimens were then embedded in paraffin, cut in 3 to 7 um thickness cross sections and stained with hematoxyline-eosin and Masson trichrome stain.

Sections were examined in a light microscope, connected to a camera and microcomputer Pentium 233Mhz equipped with IMAGE-PRO ${ }^{\circledR}$ PLUS - Version 3.0 software for morphometrical measurements. The images were manipulated in Adobe Photoshop6.0 with magic wand and rubber tools to delimit only the bone tissue. The bone neoformation area was measured in micrometers using Image J 1.38x software.

\section{Statistical analysis}

The statistical proceedings were carried out with Statistical Package Social Sciences (SPSS) version 11.0 Windows. ANOVA and Tukey were used for all comparisons between groups and periods. The level of significance alpha was set at $5 \%$. To perform the statistical analysis, 9 sections were used, 3 of each animal, with good technical view of the bone defect in order to allow comparisons among groups.

\section{Results}

In the Table1, period 4 days showed null variation and thus these groups were not compared.

TABLE1 - Quantity in square micrometers of bone neoformation according to sacrifice time and irradiation dose in Gy.

\begin{tabular}{ccccccc}
\hline $\begin{array}{c}\text { Time } \\
\text { (days) }\end{array}$ & Group & Mean & Median & Minimum & Maximum & $\begin{array}{c}\text { Standard } \\
\text { deviation }\end{array}$ \\
\hline 4 & $30 \mathrm{~Gy}$ & 0.0 & 0.0 & 0.0 & 0.0 & 0.0 \\
& $7 \mathrm{~Gy}$ & 0.0 & 0.0 & 0.0 & 0.0 & 0.0 \\
7 & & & & & & \\
& $30 \mathrm{~Gy}$ & 4977.1 & 0.0 & 0.0 & 44794.0 & 14931.3 \\
& $7 \mathrm{~Gy}$ & 38912.8 & 0.0 & 0.0 & 152805.0 & 54066.1 \\
14 & & & & & & \\
& $30 \mathrm{~Gy}$ & 21225.4 & 14258.0 & 0.0 & 63086.0 & 24018.1 \\
& $7 \mathrm{~Gy}$ & 131491.0 & 137656.0 & 60771.0 & 208865.0 & 52419.0 \\
21 & $30 \mathrm{~Gy}$ & 112813.0 & 135810.0 & 0.0 & 210204.0 & 92627.7 \\
& $7 \mathrm{~Gy}$ & 174431.1 & 187209.0 & 103237.0 & 193594.0 & 28904.0 \\
& & & & & & \\
56 & $30 \mathrm{~Gy}$ & 53892.6 & 8449.0 & 0.0 & 224679.0 & 90457.2 \\
& $7 \mathrm{~Gy}$ & 148847.4 & 151549.0 & 52707.0 & 283601.0 & 67705.9 \\
& & & & & & \\
84 & $30 \mathrm{~Gy}$ & 121003.8 & 124465.0 & 0.0 & 268553.0 & 111498.7 \\
& $7 \mathrm{~Gy}$ & 256188.1 & 277887.0 & 199200.0 & 299568.0 & 44781.1 \\
\hline
\end{tabular}

TABLE2 - Comparison of results among periods in the group exposed to $30 \mathrm{~Gy}$ irradiation.

\begin{tabular}{ccc}
\hline \multicolumn{2}{c}{ Periods } & Conclusion \\
\hline 7 & 14 & $7=14(\mathrm{p}=0.540)$ \\
7 & 21 & $7=21(\mathrm{p}=0.062)$ \\
7 & 56 & $7=56(\mathrm{p}=0.619)$ \\
7 & 84 & $7=84(\mathrm{p}=0.102)$ \\
& & \\
14 & 21 & $14=21(\mathrm{p}=0.131)$ \\
14 & 56 & $14=56(\mathrm{p}=0.890)$ \\
14 & 84 & $14=84(\mathrm{p}=0.188)$ \\
21 & 56 & $21=56(\mathrm{p}=0.746)$ \\
21 & 84 & $21=84(\mathrm{p}>0.999)$ \\
56 & 84 & $56=84(\mathrm{p}=0.725)$ \\
\hline
\end{tabular}


TABLE 3 - Comparison of results among periods in the group exposed to $7 \mathrm{~Gy}$ irradiation.

\begin{tabular}{ccc}
\hline \multicolumn{2}{c}{ Periods } & Conclusion \\
\hline 7 & 14 & $7<14(\mathrm{p}=0.020)$ \\
7 & 21 & $7<21(\mathrm{p}<0.001)$ \\
7 & 56 & $7<56(\mathrm{p}=0.017)$ \\
7 & 84 & $7<84(\mathrm{p}<0.001)$ \\
& & \\
14 & 21 & $14=21(\mathrm{p}=0.323)$ \\
14 & 56 & $14=56(\mathrm{p}=0.989)$ \\
14 & 84 & $14<84(\mathrm{p}=0.001)$ \\
& & \\
21 & 56 & $21=56(\mathrm{p}=0.894)$ \\
21 & 84 & $21<84(\mathrm{p}=0.005)$ \\
& & \\
56 & 84 & $56<84(\mathrm{p}=0.014)$ \\
\hline
\end{tabular}

TABLE 4 - Comparison of bone neoformation area among groups in each period.

\begin{tabular}{cc}
\hline Period & Conclusion \\
\hline 7 & $30 \mathrm{~Gy}=7 \mathrm{~Gy}(\mathrm{p}=0.102)$ \\
14 & $30 \mathrm{~Gy}<7 \mathrm{~Gy}(\mathrm{p}<0.001)$ \\
21 & $30 \mathrm{~Gy}=7 \mathrm{~Gy}(\mathrm{p}=0.087)$ \\
56 & $30 \mathrm{~Gy}<7 \mathrm{~Gy}(\mathrm{p}=0.023)$ \\
84 & $30 \mathrm{~Gy}<7 \mathrm{~Gy}(\mathrm{p}=0.007)$ \\
\hline
\end{tabular}

Figure 1 to 6 show histological results for 7Gy and 30Gy groups in each experimental period.

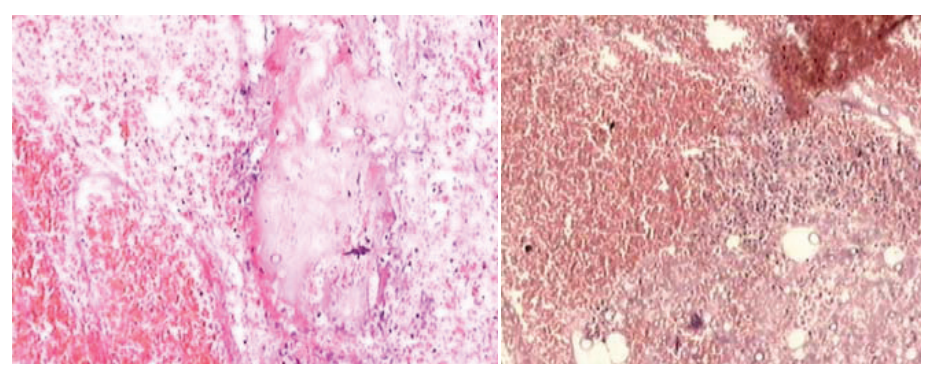

FIGURE 1 - Left 7Gy x Right 30Gy. Period of 4 days (100x). Both sides show great inflammatory infiltrate and almost no bone neoformation.

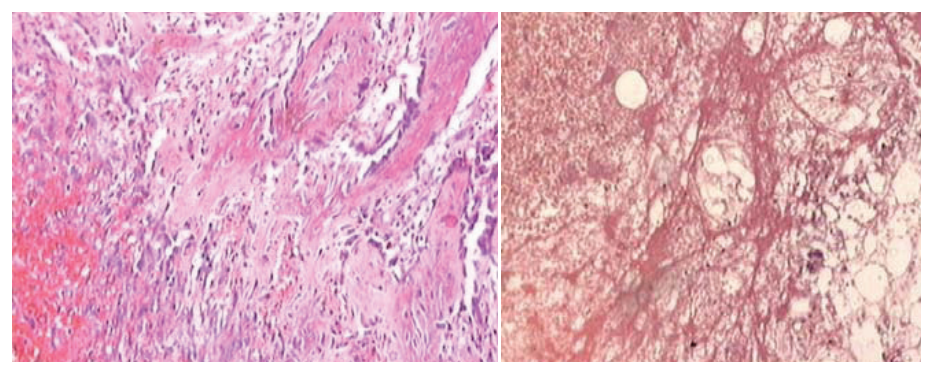

FIGURE 2 - Left 7Gy x Right 30Gy. Period of 7 days (100x). Few and similar quantity of bone neoformation between both sides.

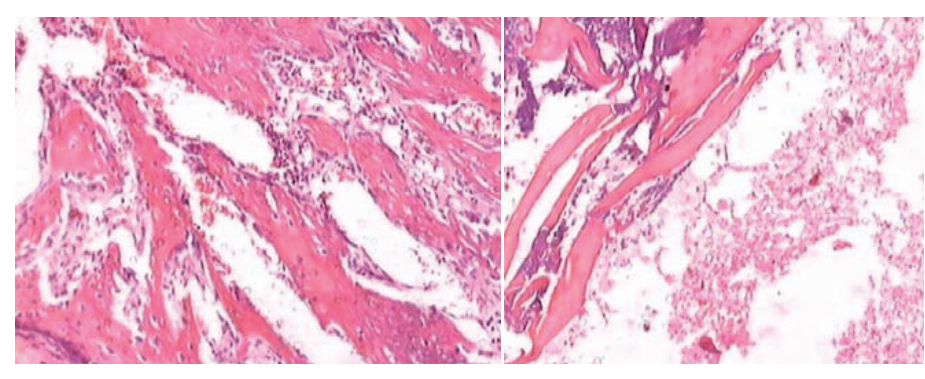

FIGURE 3 - Left 7Gy x Right 30Gy. Period of 14 days (100x). The higher dose had significantively less bone neoformation.

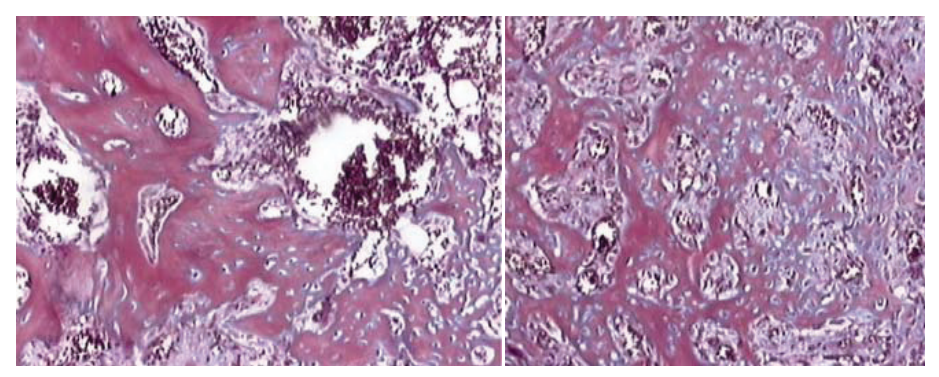

FIGURE 4 - Left 7Gy x Right 30Gy. Period of 21 days (100x). The bone neoformation was similar between sides.

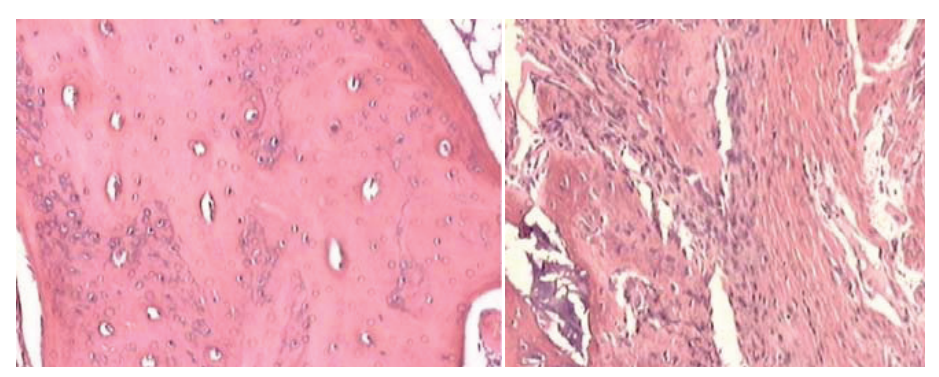

FIGURE 5 - Left 7Gy x Right 30Gy. Period of 56 days (100x). The higher dose have also showed less bone neoformation, but the difference was less significant than in the period of 14 and 84 days.

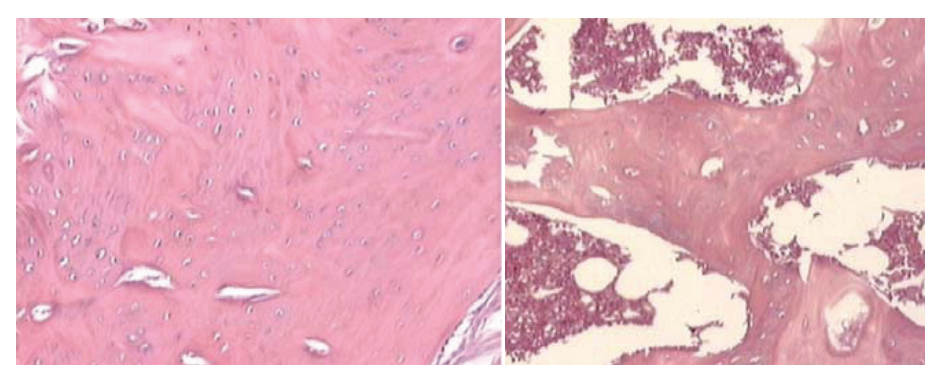

FIGURE 6 - Left 7Gy x Right 30Gy. Period of 84 days (100x). The difference between sides persisted after all study period and the left side shows more dense and mature bone.

\section{Discussion}

The purpose of this investigation was to observe the ionizing radiation effect on bone tissue, a subject that still raises 
questions and arguments about treatment and the ideal timing when they could be performed. Patients with head and neck cancer are submitted to high doses of radiation and they also suffer with the bone resection resultant of surgery. The study of risks associated with changes on quantity of newly bone formed at tumor primary site and nearby area can provide information about the time required to safe manipulation of such irradiated tissues for a dental treatment.

The effects of radiotherapy on orofacial region are greater at retromolar space and ascendant ramus, following by molars area, mandibular condyles and mental symphysis where both receive low doses of radiation ${ }^{3}$. Parliament et al. ${ }^{4}$ found that radiation dose on mandible is high in radiotherapy of nasopharynx cancer, especially at anterior region, and the thin mandibles proportionally are exposed to higher doses of irradiation.

At this present study, with 30Gy there was not progressive bone neoformation on the evaluated periods of time (Table 3 ). This suggests a long-lasting or even permanent effect since on $7^{\text {th }}$ day group the cellular compartment was identical to $84^{\text {th }}$ day group. Analyzing Table 4, the dose of 7Gy did not impair the increase of cell population and the quantity of newly formed bone of every late group was statistically greater than the early group, indicating less interference of low dose of irradiation on bone cells.

In the Table 5, comparisons between groups 30Gy and $7 \mathrm{~Gy}$ in each period revealed statistical difference in the periods 14 , 56 and 84 days. Both doses have provoked cellular damage in the initial periods of bone neoformation, which was worse with $30 \mathrm{~Gy}$ than $7 \mathrm{~Gy}$. Aitasalo ${ }^{7}$ observed osteoblast death with doses greater than $10 \mathrm{~Gy}$; this leads to conclusion that $7 \mathrm{Gythe}$ damage was small since from $14^{\text {th }}$ day there was a recovery in the bone neoformation.

According to the literature, damages are proportional to irradiation dose. From 10 to $20 \mathrm{~Gy}$ there were no changes in the cortical bone thickness or signs of resorption ${ }^{8,9}$. With $15 \mathrm{~Gy}$, bone neoformation is reduced from 30 to $80 \%$; 19Gyreduces to $65 \%$ and, between 22 to $25 \mathrm{~Gy}$, bone neoformation is almost completely inhibited in $95 \%{ }^{9-11}$. A dose of 30 Gyinduces apoptosis of osteocytes in the cortical bone, which reduces its thickness ${ }^{8,12,13}$, and increases the number of adipocytes in the bone marrow ${ }^{13}$. Doses between 45 and $90 \mathrm{~Gy}$ reduce the periosteal apposition, i.e., outer remodeling, but they induce an opposite reaction in the endostealapposition? ${ }^{7}$.

Bures and Wuehrmann ${ }^{7}$ found that high doses of radiation reduce the periosteal apposition in non-irradiated tibiae of rats, suggesting effect of secondary radiation, but they did not measure the dose. With low doses as 2,5Gy and 5Gy studied by Jacobsson et $a l .{ }^{5}$, quite similar to $7 \mathrm{~Gy}$ measured in the right tibia of this study, results have a wide range: from increasing in the bone neoformation up to decreasing. However, the newly formed bone is disorganized, shows great amount of fibrotic tissue ${ }^{5,6}$. Arnold et $a l .{ }^{9}$ also observed increasing in bone neoformation with doses of 10 to $13 \mathrm{~Gy}$, and they concluded that late remodeling was inhibited. On the other hand, Da Cunha et al. ${ }^{13}$ found changes only in the cortical bone of non-irradiated tibiae that were similar to irradiated tibiae, but no changes in the bone marrow.

Changes in the bone turnover also can be sequels of damages to vascular architecture. Vascular patency, i.e., vessel diameter, is significantly reduced after irradiation ${ }^{14}$. Moreover, there are also thrombus formation and red cells extravasation, which prejudice bone nutrition ${ }^{6,15-17}$. Following initial damage, vessels increase the diameter in response to abnormal bone associated with development of the bone neoformed, irregular and immature ${ }^{10}$.

These alterations on bone turnover in facial region can be result of radiotherapy in any part of body, for instance, breast cancer treatment. Despite careful delimitation of irradiation field and protection of adjacent area, ionizing effects can propagate into tissues and provoke changes far from the primary site. However, the dose that reaches to distant tissues and the degree of changes were evaluated only by Da Cunha et al. ${ }^{13}$.Thus, protocol that establishes when these tissues can be manipulated is lack and there still are doubts on action of low doses of irradiation in the bone that could be object of dental implants or other dental treatments.

\section{Conclusion}

Tibiae submitted to radiation dose of $30 \mathrm{~Gy}$ have shown more damage to bone cells than tibiae that received secondary radiation dose of $7 \mathrm{~Gy}$, especially observed on periods of 14,56 and 84 postoperative days. It suggests that greater dose of irradiation more damage is seen in the bone neoformation.

\section{References}

1. Glanzmann C, Grätz KW. Radionecrosis of the mandibula: a retrospective analysis of the incidence and risk factors. Radiother Oncol. 1995;36(2):94-100.

2. Curi MM, Dib LL. Osteoradionecrosis of the jaws: a retrospective study of the background factors and treatment in 104 cases. J Oral Maxillofac Surg. 1997;55(6):540-6.

3. Jereczek-Fossa BA, Garibaldi C, Catalano G, d'Onofrio A, De Pas T, Bocci C, Ciocca M, DePaoli F, Orecchia R. Analysis of mandibular dose distribution in radiotherapy for oropharyngeal cancer: dosimetric and clinical results in 18 patients. Radiother Oncol. 2003;66(1):49-56.

4. Parliament M, Alidrisi M, Munroe M, Wolfaardt J, Scrimger R, Thompson H, Field C, Kurien E, Hanson J. Implications of radiation dosimetry of the mandible in patients with carcinomas of the oral 
cavity and nasopharynx treated with intensity modulated radiation therapy. Int J Oral Maxillofac Surg. 2005;34(2):114-21.

5. Jacobsson M, Jönsson A, Albrektsson T, Turesson I. Alterations in bone regenerative capacity after low level gamma irradiation: a quantitative study. Scand J Plast Reconstr Surg. 1985;19(3):231-6.

6. Aitasalo K. Bone tissue response to irradiation and treatment model of mandibular irradiation injury: an experimental and clinical study. Acta Otolaryngol Suppl. 1986;428:1-54.

7. Bures MF, Wuehrmann AH. Bone remodeling dynamics following local x-irradiation. II. J Dent Res. 1969;48(5):904-8.

8. Ohrnell LO, Branemark R, Nyman J, Nilsson P, Thomsen P. Effects of irradiation on the biomechanics of osseointegration: an experimental in vivo study in rats. Scand J Plast Reconstr Surg Hand Surg. 1997;31(4):281-93.

9. Arnold M, Stas P, Kummermehr J, Schultz-Hector S, Trott KR. Radiation-induced impairment of bone healing in the rat femur: effects of radiation dose, sequence and interval between surgery and irradiation. Radiother Oncol. 1998;48(3):259-65.

10. Albrektsson T, Jacobsson M, Turesson I. Irradiation injury of bone tissue. A vital microscopic method. Acta Radiol Oncol. 1980;19(3):235-9.

11. Jacobsson M, Kälebo P, Albrektsson T, Turesson I. Provoked repetitive healing of mature bone tissue following irradiation: a quantitative investigation. Acta Radiol Oncol. 1986;25(1):57-62.

12. Baserga R, Lisco H, Cater DB. The delayed effects of external gamma irradiation on the bones of rats. Am J Pathol. 1961;39:45572 .

13. Da Cunha SS, Sarmento VA, Ramalho LMP, Freitas AC, Almeida D, Tavares ME, Souza JC, Veeck EB, Costa NP. Efeitos da radioterapia no tecido ósseo. Radiol Bras. 2007;40(3):189-92.

14. King MA, Casarett GW, Weber DA. A study of irradiated bone: I. Histopathologic and physiologic changes. J Nucl Med. 1979;20(11):1142-9.

15. Jacobsson M, Albrektsson T, Turesson I. Dynamics of irradiation injury to bone tissue: a vital microscopic investigation. Acta Radiol Oncol. 1985;24(4):343-50.
16. Sugimoto M, Takahashi S, Toguchida J, Kotoura Y, Shibamoto Y, Yamamuro T. Changes in bone after high-dose irradiation. Biomechanics and histomorphology. J Bone Joint Surg Br. 1991;73(3):492-7.

17. Gumieiro EH,Abrahão M, Jahn RS, Segretto H, Alves MT, Nannmark U, Granström G, Dib LL. Platelet-rich plasma in bone repair of irradiated tibiae of Wistar rats. Acta Cir Bras. 2010;25(3):257-63.

\section{Correspondence:}

Arnaldo Guilherme

Rua Caiova, 664

05018-001 São Paulo - SP Brasil

Tel/Fax: (55 11)3868-0818

dr.arnaldo.guilherme@terra.com.br

Received: April 14, 2011

Review: June 15, 2011

Accepted: July 18, 2011

Conflict of interest: none

Financial source: none

${ }^{1}$ Research performed at the Department of Otorhinolaringology and Head and Neck Surgery, Federal University of Sao Paulo (UNIFESP), Brazil. Part of Master degree thesis. Tutor: Arnaldo Guilherme. 